\title{
РЕЦЕПЦИЯ КАК ИСТОРИЧЕСКАЯ ФОРМА ПРАВОВОЙ АККУЛЬТУРАЦИИ
}

\begin{abstract}
Аннотация. В статье исследуется рецепция как историческая фрорма правовой аккультурации. Под правовой аккультурацией понимается продолжительный контакт правовых культур различных социумов, использующий в зависимости от исторических условий разнообразные методы и способы воздействия, необходимым результатом которого является изменение первоначальных структур контактируемых культур и формирование единого правового пространства. В зависимости от конкретных культурно-исторических условий различаются такие исторические фрормы правовой аккультурации, как рецепция, экспансия, ассимиляция, интеграция, конвергенция и др. Наиболее изученной формой правовой аккультурации является правовая рецепция - это историческая форма правовой аккультурации, под которой понимают односторонний добровольный процесс передачи элементов правовой культуры социума-донора с обязательным их усвоением социумом-реципиентом. Инициатором рецепции выступает принимающая сторона в лице правящей элиты, которая хочет внедрить у себя частично или полностью правовую систему донора. Результатом рецепции является частичное усвоение обществом-реципиентом культурно-правовых традиций, идей, ценностей общества-донора при сохранении своих национальных особенностей. Правовая рецепция как историческая форма правовой аккультурации обладает родовыми признаками последней и имеет ряд существенных особенностей.
\end{abstract}

Ключевые слова: юриспруденция, право, культура, аккультурация, правовая аккультурация, рецепция, межкультурный контакт, правовая культура, экспансия, социум.

DOI: 10.7256/1994-1471.2014.1.8908

$\mathrm{M}$ ежкультурная коммуникация является неотъемлемым фактором развития современных социумов различных масштабов (от семьи до цивилизаций). Данный процесс длительного культурного контакта в науке получил название аккультурации, т.е. это исторический процесс длительного межкультурного контакта, в результате которого представители одной культуры перенимают нормы, ценности и традиции другой культуры и формируется единое (общее) культурное пространство.

В условиях новой социальной реальности проблемы межкультурного контакта стали предметом изучения почти всех гуманитарных наук. К теории аккультурации проявили интерес антропологи, психологи, культурологи, философы, педагоги, историки, политологи, социологи, экономисты. Сравнительно недавно аккультурация стала предметом самостоятельного исследования в отечественной и зарубежной юриспруденции (А.Е. Абрамов, А.Г. Гузнов, И.А. Кузьмин, Л.В. Сокольская, С.А. Софронова, В.Л. Перунова, Е.А.Тверякова, В.И.
Фатхи). Но до сих пор отсутствуют фундаментальные теоретические разработки, а «именно фундаментальные аккультурационные исследования до сих пор актуальны. Благодаря постоянно появляющимся работам, которые затрагивают малоизученные или вообще новые аспекты этой проблемы, теория правовой аккультурации дополняется новыми идеями и тем самым развивается и совершенствуется» ${ }^{1}$.

На основе анализа широкого спектра научной литературы сформулировано следующее определение правовой аккультурации, под которой понимается продолжительный контакт правовых культур различных социумов, использующий в зависимости от исторических условий разнообразные методы и способы воздействия, необходимым результатом которого является изменение первоначальных структур

${ }^{1}$ Ушанова И.А. Перспективы развития теории аккультурации в глобализованном мире// Вестник Новгородского университета. 2003. №4. С.65.

(C) Сокольская Людмила Викторовна

Кандидат юридических наук, доцент кафедры гражданско-правовых дисциплин Московского государственного областного гуманитарного института [law2012@mgogi.ru]

142605, Россия, Московская область, г. Орехово-Зуево, ул. Лопатина, д.16 
контактируемых культур и формирование единого правового пространства. ${ }^{2}$

От других культурных контактов правовая аккультурация отличается определенными признаками: 1) Это результативный процесс взаимодействия правовых культур различных социумов; 2) Частичная или полная трансформация одной или нескольких контактируемых правовых культур; 3) В результате межкультурного контакта возникают новые формы культуры и образы жизни, формируется единое правовое пространство; 4) Процесс правовой аккультурации длителен во времени; 5) Правовая аккультурация не всегда предполагает равенство взаимодействующих правовых культур, взаимодействие между ними может носить добровольный, вынужденный или принудительный характер; 6) Взаимодействие возможно только однопорядковых культурных систем; 7) При правовой аккультурации этнические, религиозные и другие культурные дифференциации могут сохраняться (например, на основе политико-правового института «гражданства», сохраняется толерантное отношение к обычаям и традициям чужой культуры); 8) Процесс правовой аккультурации не всегда инициируется государственной властью, т.е. носит волевой характер, иногда он инициируется снизу, самим обществом; 9) Механизм правовой аккультурации модифицируется в зависимости от культурно-исторических условий.

В ходе исторического процесса изменяются социально-экономические, политико-правовые обстоятельства контакта правовых культур, меняется сам характер мировосприятия, а значит и сами правовые культуры. В зависимости от конкретных культурно-исторических условий различаются такие исторические формы правовой аккультурации, как рецепция, экспансия, ассимиляция, интеграция, конвергенция и др.

Наиболее изученной формой правовой аккультурации является правовая рецепция процесс заимствования и усвоения каким-либо обществом элементов правовой культуры другого общества. Правовая рецепция характерна для многих исторических этапов развития общества и государства. Поэтому неслучайно в научной литературе рецепцию изучали именно в историческом аспекте при исследовании различных правовых культур и их влияния друг на друга. Классическим историческим примером является рецепция римского права,

См.: Сокольская Л.В. Понятие и признаки правовой аккультурации //Lex russica. 2009. №3 . С.557-570 и Она же: Этапы правовой аккультурации в России //Lex russica. 2009. №2. C. 396-410. когда элементы римского права были реципированы государствами Западной Европы. Но до этого факта само римское право рецепировало институт ипотеки из греческого права, правила об аварии из финикийского. Это означает, что культурный обмен между социумами невозможно ограничить только рамками одной рецепции. Этот комплексный культурно-правовой процесс становления, развития и взаимодействия правовых культур возможно раскрыть только через такой правовой феномен, как правовая аккультурация.

Современное исследование правовой рецепции предполагает общетеоретическое осмысление накопленного исторического опыта. Отечественные правоведы все чаще пытаются сформулировать общее определение правовой рецепции, выделить ее характерные признаки и раскрыть ее содержание. В юридических словарях мы находим следующие определения данного феномена. Рецепция это - «заимствование чужеземного права» ${ }^{3}$, «заимствование и приспособление к условиям какой-либо страны права, выработанного в ином государстве или в предшествующую историческую эпоху», ${ }^{4}$ «процесс заимствования или воспроизведения» 5 , «процесс взаимодействия, заимствования, восприятия какой-либо внутригосударственной правовой системой принципов, институтов, основных черт другой внутригосударственной правовой системы». ${ }^{6}$ Приведенные выше определения являются обобщенными и не раскрывают сущность рецепции как формы правовой аккультурации. В научных работах не все исследователи формулируют четкое определение рецепции. Например, М.А. Пшеничнов под рецепцией понимает «принятие государством норм национального права, текстуально повторяющих нормы иной системы права, а также конкретизирующих и адаптирующих их к особенностям социального строя и правовой системы страны-реципиента». ${ }^{7}$ В.А. Летяев вообще уходит от конкретизации понятия, оставляя этот вопрос на рассмотрение авторам научных работ «... термин «рецепция» может иметь расширенное толкование, степень которого может оговорить сам автор научного

\footnotetext{
Юридический словарь. М., 1953. С. 575.

4 Большая советская энциклопедия. Т.22. М., 1975.
} C.188.

Большой юридический словарь/Под ред. А.Я. Сухарева, В.Д. Зорькина В.Е. Крутских. М., 1998.С.597.

6 Энциклопедический юридический словарь. М., 1999. C.255.

Пшеничнов М.А. Конституция России и международное право: проблемы взаимодействия. Автореф. дисс. ... канд. юрид. наук. Н.Новгород, 2002. С.16. 
исследования». ${ }^{8}$ Отличное от других определений содержание рецепции раскрывает Ю.Н. Фольгерова в своей диссертации. Она рассматривает рецепцию права как процесс заимствования одним государством опыта правового регулирования национальной правовой системы другого государства (других государств)». ${ }^{9}$ В диссертации Е.А. Тверяковой термин «рецепция» имеет более широкое содержание, включающее в себя не только процесс переноса норм права, но и их внедрения и усвоения социумом-реципиентом. ${ }^{10}$ С.В. Ткаченко, анализируя определения правовой рецепции, пришел к выводу, что современная российская наука в целом рассматривает рецепцию права как добровольный процесс по заимствованию и внедрению правовых ценностей иностранного происхождения. Полагая, что данное определение не отражает действительного характера современной правовой рецепции, автор предлагает вычленить ее идеологический компонент и исследует рецепцию права как заимствование и внедрение идей, правовых институтов, норм, терминологии иностранного права в силу идеологии реципиента и (или) донора. ${ }^{11}$ Исходя из идеологического компонента рецепции права, для определения характера современной российской рецепции автор вводит термин «декоративная рецепция». По его мнению, декоративная рецепция возникает в качестве спасительной идеи для правящей элиты заимствования правовых «благ» более передовых цивилизаций в момент государственно-правового и экономического кризиса.

В.В. Мантуров предлагает исследовать процесс рецепции в узком и широком понимании и отличать его от иных форм культурного контакта. В результате, окончательно запутавшись, он не смог «разорвать порочный круг терминологии» и сформулировать четкие дефиниции, поэтому в заключении просто констатирует, что «... рецепция права представляет собой не просто технический перенос правовых норм иностранного права в российские законы, процесс рецепции гораздо слож-

\footnotetext{
Летяев В.А. Необходимость и достаточность рецепции норм римского права в России XIX-начала XX вв. // Древнее право. 2004. №1.С.194.

9 Фольгерова Ю.Н. Преемственность и рецепция в конкурсном процессе стран Западной Европы и России: историко-сравнительный анализ.Автореф. дисс. ... канд. юрид. наук. Киров.-2008. С.7.

10 См.: Тверякова Е.А. Юридическая экспансия: теоретико-историческое исследование. Автореф. дисс. ... канд. юрид. наук. М., 2002.

11 См.: Ткаченко С.В. Правовые реформы в России: проблемы рецепции Западного права. Самара, 2008 C.3-24;
}

нее переносится. Кроме того, данный процесс включает в себя адаптацию норм и идей, и их внедрение в правовую систему». ${ }^{12}$ Как видим, ничего нового в данном определении нет, все сведено к процессу переноса, адаптации и внедрения элементов правовой культуры одного социума в другой.

Правовая рецепция как историческая форма правовой аккультурации обладает родовыми признаками последней и имеет ряд существенных особенностей. Можно выделить следующие основные качественные характеристики правовой рецепции: она имеет добровольный, односторонний характер; инициатором выступает социум-реципиент в лице политической (правящей) элиты, обеспечивается государственной волей (например, волей законодателя).

Важнейшая особенность правовой рецепции заключена в ее политической (властной) природе. Она в отличие от иных исторических форм правовой аккультурации не может начаться изнутри общества, она обязательно осуществляется по воле государства, носит исключительно волевой характер. Вспомним рецепцию византийского права Киевской Русью. Принятие христианства и основ византийского права осуществлялись княжеской властью. Историко-правовая наука определяет источники византийского права, которые были реципированы Киевской Русью - это Номоканоны Иоанна Схоластика и патриарха Фотия, Эклога, Прохирон, Эпанагога, Василики, Собрание новелл императора Льва VI и др. Но Великие князья Киевские заимствовали только нормы светско-канонического права, учреждили церковный суд и определили виды правонарушений ему подсудных. В дальнейшем эти нормы компилируются Кормчими книгами и древнерусскими каноническими сборниками. Однако основой функционирования княжеского суда остаются нормы обычного права и княжеские указы, закрепленные в Русской Правде. Таким образом, на древнерусском правовом пространстве функционировали параллельно две правовые системы - княжеская (светская) и каноническая (религиозная). Властная природа правовой рецепции проявляется и в период осуществления правовых реформ в Российской Империи 1864 года, когда чиновникам Государственной канцелярии официально было дозволено применять в своей деятельности западные принципы и модели. И в США введение властями кодексов привело к изменению техники правоприменительной работы, к заимствованию ряда элементов римского права,

12 Мантуров В.В. Соотношение рецепции и иных форм правовых заимствований. // Сибирский юридический вестник. 2012. №4. С.109. 
в частности императивных методов договорного права. ${ }^{13}$

Другим характерным признаком рецепции является добровольность принимающей стороны. В юридической науке этот постулат фактически не оспаривается (кроме С.В. Ткаченко). Так, М. Ансель рассматривает рецепцию права как «наиболее полную форму преднамеренного, добровольного сближения правовых систем» ${ }^{14}$, а Г.И. Муромцев подчеркивает, что правовая рецепция предполагает только добровольное восприятие иностранного права в качестве регулятора отношений данного общества. ${ }^{15}$ Последующие исследователи, такие как В.А Томисинов, Г.М. Азнагулова, О.В. Мартышин, С.А. Сафронова, В.В. Мантуров и другие только констатируют данный факт. ${ }^{16}$ Работа С.В Ткаченко привносит диссонанс в данное утверждение. В частности он утверждает, что констатация «добровольности» рецепции приводит к игнорированию либо подтасовке исторических фактов. И далее, приводя примеры послевоенной Японии, реформирования в XIX- XX вв. уголовного права Турции, Ирана, Египта, принятие Конституции РФ 1993 г., вступление в ЕС новых государств автор рассуждает о принудительной рецепции. Позволим не согласиться с подобным мнением, т.к. термин «добровольность» подразумевает волю политической (правящей) элиты. Если правительство заинтересовано в перенимании правового опыта иностранных государств, осознает необходимость данного процесса и выступает инициатором политико-правовых преобразований, то можно говорить о добровольности рецепции. Решение о реципировании правовых норм, идей и принципов может приниматься властью спонтанно или преднамеренно, оно может быть обусловлено экономическим, политическим давлением, но это будет именно властное решение, за которое придется нести политическую ответственность.

13 Егоров А.В. Правовая интеграция и ее содержание// Государство и право. 2004. №6. С.81.

14 Ансель М. Методологические проблемы сравнительного права // В кн.: Очерки сравнительного права. M., 1981.C. 63.

15 Муромцев Г.И. Источники права в развивающихся странах Азии и Африки: система и влияние традиции. M., 1987. C.10;

16 Томсинов В.А. О сущности явления, называемого рецепцией римского права // Вестник МГУ. Серия : Право.- 1998., № 1; Азнагулова Г.М. Рецепция права как форма взаимодействия национальных правовых систем. Автореф. дисс. ... канд. юрид. наук. Уфа, 2003; Мартышин О.В. Национальная политическая и правовая культура в контексте глобализации //Государство и право. 2005. .№4.
В качестве следующего признака рецепции выделяется ее односторонний характер. Рецепция - это односторонний акт государства, «импортирующего» элементы иной правовой системы. ${ }^{17}$ По мнению Д. Аджани, для развития правовой системы характерна периодическая рецепция, которая во все исторические периоды, как правило, происходила и происходит по инициативе принимающей правовой системы. ${ }^{18}$ Итак, правовая рецепция - это односторонний процесс, инициатором которого выступает правящая элита социума-реципиента. Классическим историческим примером считается рецепция римского права в Западной Европе, когда юридические формулы толковались средневековыми юристами уже после распада Римской империи и самого существования римского права. Но в современном мире социум-донор не столь безразличен к результату рецепции. Как правило, он заинтересован в расширении своего влияния, поэтому опосредованно способствует данному процессу. Если социум-донор открыто применяет силовые методы и средства, то это уже будет не рецепция, а экспансия или ассимиляция. Данные формы правовой аккультурации будут рассмотрены далее.

Итак, правящая элита осознает по экономическим, политическим или иным причинам, что необходимо собственную правовую систему изменить, т.к. нарождающиеся общественные отношения уже не могут быть урегулированы старыми правовыми нормами. Так было в Западной Европе, когда развитие товарно-денежных отношений привело к рецепции частного римского права. В данном случае власть определяет, каким способом осуществить подобные изменения: путем заимствования иностранного правового опыта или преемственности. И то и другое выступают как пути правовой аккультурации, только с разными векторами направленности. Заимствование - это привнесение элементов правовой культуры из вне, т.е. общество-реципиент воспринимает образцы чужого права, выработанные обществом донором в эту же историческую эпоху. А преемственность - это обращение к собственному историческому опыту или восприятие чужого права, созданного в предшествующие исторические эпохи. Теоретическим основанием данной модели служит общепринятое положение о том, что право есть продукт предшествующего культурного развития общества и резуль-

Кулагин М.И. Предпринимательство и право: опыт Запада / Кулагин МИ. Избранные труды. М., 1997. C.216.

18 Ajani D. By Chance and Prestige: Legal Transplants in Russia and Eastern Europe// American Journal of Comparative law. Vol. 43.- 1995. № 1 (Winter). P.97 
тат взаимодействия с современными внешними культурно-правовыми формами.

Правовое заимствование - это осознанная односторонняя деятельность определенных субъектов по применению элементов иностранной правовой культуры в национальной правовой среде. Необходимость заимствования элементов правовой культуры социума-донора обусловлена появлением новых социальноэкономических отношений, формированием потребности их урегулировать на государственном уровне (как альтернативный вариант можно вспомнить так называемую теневую экономику в советском государстве). После чего власть вырабатывает модель переноса чужеродных элементов в национальную правовую систему. Перенесенные правовые элементы могут адаптироваться к новым социокультурным условиям или быть отторгнуты обществом. «Любая правовая культура обладает способностью как ассимиляции (адаптации - термин наш Л.С.), так и к отторжению чужеродного ей юридического материала, чрезмерные дозы которого, массированно введенные в правовую систему, могут дезорганизовать и дестабилизировать правопорядок, внести негоэлементы борьбы различных начал». ${ }^{19}$ Отторжение может быть частичным или абсолютным. Например, в ходе рецепции швейцарского гражданского кодекса в Турции позднее произошло отторжение некоторых законодательных положений, в частности снижение брачного возраста и установление обязательной регистрации перехода собственности в определенных кланах. Конституция Казахстана 1993 г., разработанная на основе конституционной модели США, не смогла функционировать в реформируемом обществе и была отменена в 1995 году в связи с принятием новой конституции Республики Казахстан.

После адаптации, принятия чужеродных культурно-правовых форм наступает их введение в действие, законодательное закрепление. Правовая система социума-реципиента определяет результативность функционирования привнесенного правового элемента в отечественных социокультурных условиях. К сожалению, не всегда привнесенные элементы оказывают на общество-реципиент положительное, прогрессивное влияние. Мы можем вспомнить неудачный пример рецепции иностранного права Россией в период столыпинской реформы. Механически насаждавшийся западный опыт фермерско-хуторского хозяйствования не только не привел к прогнозируемому социально-экономическому процве-

19 Саидов А.Х. Сравнительное правоведение. М., 2000. C.418. танию России, но и настроил крестьянство против власти, что и стало одной из причин революции 1917 г. А суд присяжных на российской почве из судебного органа превратился в политический инструмент и фактически привел к безнаказанности российского терроризма (например, судебный процесс по делу революционерки В.И. Засулич).

Но если по прошествии определенного времени заимствованный элемент приживается, то он становится достоянием отечественного правового опыта. Вспомним институт присяжных заседателей. Некоторые исследователи (Л.А. Петручак, Г.В. Санкевич) полагают, что данный институт появился благодаря «обращению юристов к отечественной правовой традиции». Однако суд присяжных заседателей был заимствован Россией из других правовых систем в ходе реформы 1864 года.

Процесс заимствования иных культурно-правовых форм распадается на определенные стадии. Первая стадия-выявление потребности. На данном этапе в обществе-реципиенте появляются новые или претерпевают изменения социально-экономические отношения, а существующий механизм правового регулирования не дает нужного результата. Поэтому возникает потребность в заимствовании сходных правовых элементов из другой социально-экономической среды. Вторая стадия - заимствование. Это перенос правовых норм и институтов из одной правовой системы в другую. На этом этапе законодатель согласовывает принципы и идеи чужого права с внутригосударственным правом и практикой его применения; анализирует и оценивает сравнительно правовые данные о развитии законодательства в обоих социумах; изучает и сопоставляет зарубежный опыт по применению приемов юридической техники с национальным опытом; составляет прогноз и рекомендации по внедрению зарубежной модели права. Третья стадия - адаптация. Данный этап необходим для успешного применения правовых норм и институтов с учетом сложившихся национальных правовых обычаев и традиций. Заимствованные элементы должны адаптироваться в суверенной национальной правовой системе, стать ее частью. Четвертая стадия - восприятие (усвоение). На этом этапе происходит процесс принятия и введение в действие чуждых правовых принципов, норм и институтов в правовой системе реципиента. На законодательном уровне они закрепляются и получают официальное признание, применяются на практике. Пятая стадия - резульmam. Результативность и устойчивость функционирования правовых норм и институтов в новой среде. Это может выражаться в наличии 
определенного социального эффекта в виде уважения закона, повышения качества законотворческой деятельности, снижения уровня преступности, соблюдения законности и др. Частичное сохранение национальной правовой культуры. Зарождение новой культурной системы, формирование единого правового пространства и регионального (глобального) права.

Рецепция в праве может рассматриваться как разновидность преемственной связи. Связь между правовыми системами в рамках определенного исторического типа права имеет характер рецепции, восприятия, в основе которого лежит наличие общих закономерностей и сходных условий развития. Следовательно, рецепция в форме преемственности возможна лишь при наличии одинаковых социально-экономических отношений, историко-типологической совместимости взаимодействующих социумов.

Известный болгарский правовед Н. Неновски также рассматривает рецепцию «как пример преемственности, основывающейся главным образом на экономических, базисных факторах», ${ }^{20}$ в частности, в качестве причины реципирования частного римского права он называет развитие товарно-денежных отношений. Реципируемое явление должно органически слиться с принимающей его правовой средой, в противном случае нет смысла говорить о рецепции вообще.

Правовая преемственность имеет ярко выраженный исторический характер. Профессор Г.В. Мальцев верно подчеркивает, что «право движется по собственному кругу с обязательным возвратом в исходные точки». ${ }^{21}$ Именно культурно-правовые традиции народа позволяют обществу сохранить исторические особенности предшествующих поколений даже под воздействием агрессивного внешнего влияния.

Процесс переноса культурных ценностей из одного исторического этапа развития правовой системы в другой не всегда сопровождается положительным результатом, он может быть консервативным, реакционным и т.д. В своей монографии Н. Неновски отмечает, что «преемственность в праве означает связь между разными этапами (ступенями) в развитии права как социального явления, что суть этой связи состоит в сохранении определенных

20 Неновски Н. Преемственность в праве. М., 1977. С. 46. Аналогичное мнение высказывает М.К. Бункина См.: Бункина М.К. Взаимозависимость, интеграция, общеевропейский дом // Советское государство и право. 1989. № 10. С. 130.

21 Мальцев Г.В. Очерк теории обычая и обычного права//Обычное право в России: проблемы теории, истории и практики. Ростов-на-Дону, 1999. С.96. элементов или сторон права (в его сущности, содержании, форме, структуре, функциях и др.) при соответствующих его изменениях». ${ }^{22}$ Анализируя связь между преемственностью и рецепцией автор, по нашему мнению, формулирует ошибочный вывод о том, что рецепция это специфическое проявление преемственности в праве. Мы полагаем, что рецепция - более емкое понятие. Оно включает в себя не только сохранение собственных элементов правовой культуры при переходе в качественно новое состояние этой же правовой системы, но и принятие чужих элементов из правовых систем других государств, параллельно развивающихся в эту эпоху. Поэтому мы разделяем точку зрения на проблему соотношения категорий рецепция и преемственность В.В. Мантурова, который считает, что «преемственность, характеризующаяся только историческим аспектом, является составной частью рецепции, охватывающий как прошлый опыт, так и существующие на данный момент идеи и нормы». ${ }^{23}$

Исходя из вышеизложенного, целесообразно различать два типа правовой рецепции:

Во-первых, рецепция по горизонтали (заимствование) - восприятие правовых институтов и явлений одной стороной от другой, когда обе правовые культуры существуют одновременно. Термин «рецепция» в данном случае употребляется для обозначения восприятия каким-либо правовым порядком действующих норм современной культурной системы. Горизонтальная рецепция может быть двухсубъектной (одностороннее заимствование культурно-правовых форм социума-донора социумом-реципиентом) и многосубъектной (одностороннее заимствование социумом-реципиентом культурно-правовых форм нескольких доноров). Примером двухсубъектной горизонтальной рецепции может выступать восприятие арабской культурой в VII-IX веках культуры и права завоеванных народов Сирии, Палестины и Ливана. Примером многосубъектной рецепции может служить история древнеримского права, которое органично восприняло достижения правовых культур различных народов Средиземноморья, которые были полезны для Рима. Профессор Г.И. Муромцев подчеркивает, что это было не механическое копирование нормативного материала, а имел место синтез национальных правовых институтов и достижений правовых культур Средиземноморья, а в частности, греческой правовой культуры (законы

\section{2 Неновски Н. Указ. соч. С. 42.}

23 Мантуров В.В. Соотношение рецепции и иных форм заимствований//Сибирский юридический вестник. 2012. №4. С.108. 
Солона, законы Ликурга), правовой культуры Карфагена. В основе Законов XII таблиц лежит национальное римское право царского периода и греческие правовые тексты. ${ }^{24}$

Во-вторых, рецепция по вертикали (преемственность), при смене культурно-исторических этапов развития общества. Рецепция, в данном случае, предполагает восприятие не отдельных правовых норм изолированных элементов правовой формы, а системы институтов, системы правовых норм, отраслей права, находящихся в тесной связи между собой неким признанным образцом. Реципиенты выбирают не просто приемлемую систему правовых ценностей. Главное, что реципируемое право должно быть авторитетным и признанным, занимать свою нишу в правовом мировом пространстве. Это обычно право старое, традиционное, проверенное. В качестве такого образца могут выступать не только элементы иностранных правовых систем, но и свои, утраченные в прошлом. Такой тип рецепции В.Н. Синюков именует «аберративной рецепцией». По его мнению, это способность правовой системы возвращаться к своим исходным началам. Самобытные черты социалистического права в российской системе были сформированы, в основном, в результате абберативной рецепции основ русского права и преодоления формальной принадлежности законодательства Российской империи к европейскому праву. ${ }^{25}$

Для того чтобы рецепция была успешной, необходимо выполнить ряд условий:

- взаимодействие идентичных социокультурных систем;

- поэтапное восприятие элементов чужого юридического опыта: сначала система ценностей, а затем собственно правовые нормы, институты и т.д.;

- $\quad$ строго научный подход к реципируемому явлению;

- $\quad$ внедряемые элементы чужого права не должны отрицать национальные правовые традиции, юридическую практику общества-реципиента. По мнению О.В. Мартышина, успешное заимствование правовых моделей возможно только с учетом принципов и ценностей, лежащих в основе соответствующей политико-правовой культуры. ${ }^{26}$

\footnotetext{
24 Муромцев Г.И. Культура и право: аспекты соотношения // Право и культура. М., 2002. С.106-107.

25 См.: Синюков В.Н. Российская правовая система: Введение в общую теорию права. - Саратов, 1994. С.162.

26 Мартышин О.В. Национальная политическая и правовая культура в контексте глобализации //Государство и право. 2003. №10. С.26.
}

Какие же элементы чужого права являются предметом рецепции? В.А. Рыбаков предлагает исключить из данного понятия трансформацию и имплементацию норм международного права и элементы национального права из разных исторических эпох развития общества (он называет подобный процесс преемственностью и противопоставляет его рецепции), а также правосознание (особенно правовую ментальность и правовую психологию общества-донора) и правовой обычай, если его рассматривать как правило-привычку. ${ }^{27}$ Мы можем только частично согласиться с данным положением, т.к. полагаем, что заимствование и преемственность это различные пути осуществления правовой рецепции. О чем уже было изложено выше. Что же касается правосознания и правового обычая, то они как культурные феномены меньше всего подвержены реципированию. Они формируются в результате длительной общественной практики, отражают духовные ценности народа и его предрассудки. Однако человечество за свою тысячелетнюю историю выработало способность аккумулировать общечеловеческие ценности, которые сегодня одобряются многими сообществами. Чаще всего подлежат рецепированию правовые нормы, регулирующие частноправовые отношения, нежели нормы публичного права. Это обусловлено тем, что нормы, закрепляющие основы государственной власти в стране, более прочно связаны с традиционными устоями данного общества с его самоидентификацией. Например, заимствование такого демократического принципа как разделение властей и системы «сдержек и противовесов» осуществляется в различных государствах с учетом исторических, национальных, психологических особенностей общества.

Проблема реципирования элементов иностранного права достаточно актуальна для современной России. История России свидетельствует о том, что ее государственность и право развивались в русле континентальной цивилизации (сказалось длительное влияние западноевропейского права), но и имели черты, особенности восточной культуры. Отрицать влияние восточных правовых

\footnotetext{
Рыбаков В.А. Рецепция права: общетеоретический аспект//Вестник Омского университета. Серия: Право. 2007. №4. С.5-12. В более поздней его работе рецепированию подлежат не только нормы иностранного права, но и трансформация (имплементация) норм международного права. См.: Рыбаков В.А. Рецепция и правотворчество// Вестник Омского университета. Серия: Право. 2012. №2. С.16-23;
} 
ценностей на становление российской культуры нельзя, ведь на ряде этапов, например, в эпоху татаро-монгольского владычества оно было определяющим. Русская правовая культура в силу своего географического расположения, национальной и правовой ментальности формировалась как евразийская культура, которая имеет свою специфику и особенности.

На основании вышеизложенного можно сформулировать следующее определение правовой рецепции - это историческая форма правовой аккультурации, под которой понимают односторонний добровольный процесс передачи элементов правовой культуры социума-донора с обязательным их усвоением социумом-реципиентом. Инициатором рецепции выступает принимающая сторона в лице правящей элиты, которая хочет внедрить у себя частично или полностью правовую систему донора. Результатом рецепции является частичное усвоение обществом-реципиентом культурно-правовых традиций, идей, ценностей общества-донора при сохранении своих национальных особенностей.

Признавая, что рецепция - это форма аккультурации, ее иногда называют «тотальной аккультурацией» ${ }^{28}$ (глобальный процесс, изменяющий весь правовой строй общества-реципиента) или «культурной мутацией». ${ }^{29}$ Нам трудно согласиться с подобным мнением, т.к. существование тотальной рецепции маловероятно. Ни одно государство в мире не способно на добровольный полный отказ от собственных национальных правовых традиций, идеологии, государственно-правовой идентичности. А вот в процессе открытой правовой экспансии (завоевания страны) возможна юридическая декультурация, которая выражается в разрушении правовой культуры социума-реципиента и полного восприятия иностранного права завоевателей. Однако исследование правовой экспансии как исторической формы правовой аккультурации выходит за рамки данной научной работы.

\section{Библиография}

1. Ajani D. By Chance and Prestige: Legal Transplants in Russia and Eastern Europe// American Journal of Comparative law. Vol. 43.-1995. № 1 (Winter).

2. Азнагулова Г.М. Рецепция права как форма взаимодействия национальных правовых систем /Автореф. дисс. ... канд. юрид. наук. Уфа, 2003.

3. Ансель М. Методологические проблемы сравнительного права // В кн.: Очерки сравнительного права. М., 1981.

4. Большая советская энциклопедия. Т.22. М., 1975.

5. Большой юридический словарь/Под ред. А.Я. Сухарева, В.Д. Зорькина В.Е. Крутских. М., 1998.

6. Бункина М.К. Взаимозависимость, интеграция, общеевропейский дом // Советское государство и право. 1989. № 10.

7. Егоров А.В. Правовая интеграция и ее содержание//Государство и право. 2004. №6.

8. Карбонье Ж. Юридическая социология.-М., 1998.

9. Косырев А.И. Этапы рецепции римского права//Советское государство и право. - 1983. № 7.

10. Кулагин М.И. Предпринимательство и право: опыт Запада / Кулагин МИ. Избранные труды. M., 1997.

\footnotetext{
28 Примером тотальной рецепции, по мнению А.И Косарева, является полное заимствование континентальной Европой римского права. См.:Косырев А.И. Этапы рецепции римского права//Советское государство и право. - 1983. № 7.

29 См.: Карбонье Ж. Юридическая социология.- М., 1998.- С.198-200; Лотман Ю.М. Внутри мыслящих миров. - М., 1999.-С.21-22. Под культурной мутацией понимается полное изменение правовой системы социума-реципиента. В.В. Чемеринская полагает, что результатом рецепции может быть мутация воспринимаемых норм. Причина этого кроется в несовместимости реципируемого правового явления с традицией реципиента. См.:Чемеринская В.В. Влияние византийского права на древнерусское российское законодательство X-XVII вв.(опыт сравнительного анализа). Автореф. дисс. ... канд. юрид. наук. М., 2003.
} 
11. Летяев B.A. Необходимость и достаточность рецепции норм римского права в России XIX-начала ХХвв//Древнее право. 2004. №1.

12. Мальцев Г.В. Очерк теории обычая и обычного права//Обычное право в России: проблемы теории, истории и практики. Ростов-на-Дону, 1999.

13. Мантуров В.В. Соотношение рецепции и иных форм заимствований //Сибирский юридический вестник. 2012. №4.

14. Мартышин О.В. Национальная политическая и правовая культура в контексте глобализации //Государство и право. 2003. №10.

15. Муромцев Г.И. Источники права в развивающихся странах Азии и Африки: система и влияние традиции. М., 1987.

16. Муромцев Г.И. Культура и право: аспекты соотношения // Право и культура. М., 2002. С.106107.

17. Неновски Н. Преемственность в праве. М., 1977.

18. Пшеничнов М.А. Конституция России и международное право: проблемы взаимодействия / Автореф. дисс. ... канд. юрид. наук. Н.Новгород, 2002. С.16

19. Рыбаков В.А. Рецепция и правотворчество// Вестник Омского университета. Серия: Право. 2012. №2. С.16-23.

20. Рыбаков В.А. Рецепция права: общетеоретический аспект // Вестник Омского университета. Серия: Право. 2007. №4. С.5-12

21. Саидов А.Х. Сравнительное правоведение. М.. 2000.

22. Синюков В.Н. Российская правовая система: Введение в общую теорию права. - Саратов, 1994.

23. Сокольская Л.В. Понятие и признаки правовой аккультурации //Lex russica. 2009. №3 . C.557570.

24. Сокольская Л.В. Этапы правовой аккультурации в России //Lex russica. 2009. №2. C. 396-410.

25. Тверякова Е.А. Юридическая экспансия: теоретико-историческое исследование. Автореф. дисс. ... канд. юрид. наук. М., 2002

26. Ткаченко С.В. Правовые реформы в России: проблемы рецепции Западного права. Самара, 2008.

27. Томсинов В.А. О сущности явления, называемого рецепцией римского права // Вестник МГУ. Серия : Право.-1998., № 1.

28. Ушанова И.А. Перспективы развития теории аккультурации в глобализованном мире// Вестник Новгородского университета. 2003. №4.

29. Фольгерова Ю.Н. Преемственность и рецепция в конкурсном процессе стран Западной Европы и России: историко-сравнительный анализ. Автореф. дисс. ... канд. юрид. наук. Киров, 2008.

30. Чемеринская В.В. Влияние византийского права на древнерусское российское законодательство X-XVII вв.(опыт сравнительного анализа) //Автореф. дисс. ... канд. юрид. наук. М., 2003.

31. Энциклопедический юридический словарь. М., 1999..

32. Юридический словарь. М., 1953.

33. Лотман Ю.М. Внутри мыслящих миров. - М., 1999.

\section{References}

1. Ajani D. By Chance and Prestige: Legal Transplants in Russia and Eastern Europe// American Journal of Comparative law. Vol. 43.-1995. № 1 (Winter).

2. Aznagulova G.M. Retseptsiya prava kak forma vzaimodeistviya natsional'nykh pravovykh sistem. Avtoreferat diss. ... kand. yur. nauk. Ufa, 2003.

3. Ansel' M. Metodologicheskie problemy sravnitel'nogo prava // V kn.: Ocherki sravni-tel'nogo prava. M., 1981.S. 63.

4. Bol'shaya sovetskaya entsiklopediya. T.22. M., 1975.

5. Bol'shoi yuridicheskii slovar'/Pod red. A.Ya. Sukhareva, V.D. Zor'kina V.E. Krutskikh. M., 1998.

6. Bunkina M.K. Vzaimozavisimost', integratsiya, obshcheevropeiskii dom // Sovetskoe go-sudarstvo i pravo. 1989. № 10 . .

7. Egorov A.V. Pravovaya integratsiya i ee soderzhanie//Gosudarstvo i pravo. 2004. №6.

8. Karbon'e Zh. Yuridicheskaya sotsiologiya.-M., 1998.

9. Kosyrev A.I. Etapy retseptsii rimskogo prava//Sovetskoe gosudarstvo i pravo. - 1983. № 7.

10. Kulagin M.I. Predprinimatel'stvo i pravo: opyt Zapada / Kulagin MI. Izbran-nye trudy. M., 1997. 
11. Letyaev V.A. Neobkhodimost' i dostatochnost' retseptsii norm rimskogo prava v Ros-sii KhIKhnachala KhKhvv//Drevnee pravo. 2004. №1.

12. Mal'tsev G.V. Ocherk teorii obychaya i obychnogo prava//Obychnoe pravo v Rossii: problemy teorii. istorii i praktiki. Rostov-na-Donu, 1999.

13. Manturov V.V. Sootnoshenie retseptsii i inykh form zaimstvovanii//Sibirskii yuridicheskii vestnik. 2012. №4.

14. Martyshin O.V. Natsional'naya politicheskaya i pravovaya kul'tura v kontekste globalizatsii // Gosudarstvo i pravo. 2003. №10.

15. Muromtsev G.I. Istochniki prava v razvivayushchikhsya stranakh Azii i Afriki: sistema i vliyanie traditsii. M., 1987.

16. Muromtsev G.I. Kul'tura i pravo: aspekty sootnosheniya // Pravo i kul'tura. M., 2002. S.106-107

17. Nenovski N. Preemstvennost' v prave. M., 1977.

18. Pshenichnov M.A. Konstitutsiya Rossii i mezhdunarodnoe pravo: problemy vzaimo-deistviya. Avtoreferat diss. ... kand. yur. nauk. N.Novgorod, 2002.

19. Rybakov V.A. Retseptsiya i pravotvorchestvo// Vestnik Omskogo universiteta. Seriya: Pravo. 2012. №2. S.16-23.

20. Rybakov V.A. Retseptsiya prava: obshcheteoreticheskii aspekt//Vestnik Omskogo uni-versiteta. Seriya: Pravo. 2007. №4. S.5-12.

21. Saidov A.Kh. Sravnitel'noe pravovedenie. M., 2000.

22. Sinyukov V.N. Rossiiskaya pravovaya sistema: Vvedenie v obshchuyu teoriyu prava. - Saratov, 1994.

23. Sokol'skaya L.V. Ponyatie i priznaki pravovoi akkul'turatsii //Lex russica. 2009. №3 . S.557-570.

24. Sokol'skaya L.V. Etapy pravovoi akkul'turatsii v Rossii //Lex russica. 2009. №2. S. 396-410.

25. Tveryakova E.A. Yuridicheskaya ekspansiya: teoretiko-istoricheskoe issledovanie. Avtoreferat diss. ... kand. yur. nauk.M., 2002.

26. Tkachenko S.V. Pravovye reformy v Rossii: problemy retseptsii Zapadnogo prava. Samara, 2008.

27. Tomsinov V.A. O sushchnosti yavleniya, nazyvaemogo retseptsiei rimskogo prava // Vestnik MGU. Seriya : Pravo.-1998., № 1.

28. Ushanova I.A. Perspektivy razvitiya teorii akkul'turatsii v globalizovannom mire// Vestnik Novgorodskogo universiteta. 2003. №4.

29. Fol'gerova Yu.N. Preemstvennost' i retseptsiya v konkursnom protsesse stran Zapadnoi Evropy i Rossii: istoriko-sravnitel'nyi analiz. Avtoreferat diss. ... kand. yur. nauk. Kirov., 2008.

30. Chemerinskaya V.V. Vliyanie vizantiiskogo prava na drevnerusskoe rossiiskoe zakonodatel'stvo KhKhVII vv.(opyt sravnitel'nogo analiza). Avtoreferat diss. ... kand. yur. nauk. M., 2003.

31. Entsiklopedicheskii yuridicheskii slovar'. M., 1999.

32. Yuridicheskii slovar'. M., 1953.

33. Lotman Yu.M. Vnut-ri myslyashchikh mirov. - M., 1999.S

Материал получен редакцией 19 июня 2013 г. 